\title{
シリーズ教育講座「内耳形態と細胞機能の研究手法
}

\author{
9. 内耳におけるイオンチャネル測定法 \\ 山内大輔，中谷和弘
}

\section{Measuring methods of ion channel in the inner ear}

\author{
Daisuke Yamauchi, Kazuhiro Nakaya \\ Department of Otolaryngology-Head \& Neck Surgery, Tohoku University \\ Graduate School of Medicine
}

Endolymph which fills the scala media is an unusual extracellular fluid in that its composition is reminiscent of intracellular fluid such as its high potassium concentration. This characteristic ion homeostasis is important for the production of the endocochlear DC potential which is the main driving force for sensory transduction. Imbalance of ion homeostasis in the inner ear is therefore closely-linked to the pathophysiological mechanism of hearing impairment and balance disorder. Moreover, it is very important to study the physiology of ion channels in the inner ear. Ion channel measuring methods have been established electro-physiologically and recently developed using molecular physiology and molecular genetics. The ion channel's function can be measured as the result of 'ion flux' by ion selective electrodes, a vibrating probe and the Ussing chamber. In this paper, ion transport models are introduced and useful ion measuring methods are explained.

Key words: ion selective electrodes, vibrating probe, Ussing chamber, inner ear

\section{はじめに}

イオンチャネルに関しては, 様々な器官におい て, 数多くの研究が行われてきた。特に内耳では, 内リンパの特異なイオン組成を調整するイオンチ ヤネルの局在・機能解析が, 様々な研究手法によ って明らかにされてきた。本項では内耳における イオンチャネルの役割について概説しつつ, 様々 な測定手法について解説する。

\section{内リンパのイオン組成}

内耳においては内リンパ腔（膜迷路）がその周 囲の外リンパ腔 (骨迷路) と隔てられ, その特異 なイオン組成が維持されている。表 1 に示すよう

東北大学大学院 耳鼻咽喉 ·頭頸部外科学分野
に, 外リンパが体液組成とほぼ同様で $\mathrm{Na}^{+} 145$ $\mathrm{mM}, \mathrm{K}^{+} 5 \mathrm{mM}, \mathrm{Ca}^{2+} 1 \mathrm{mM}$ であるのに対し, 内 リンパは $\mathrm{Na}^{+} 1-9 \mathrm{mM}, \mathrm{K}^{+} 150 \mathrm{mM}, \mathrm{Ca}^{2+} 0.02-0.2$ $\mathrm{mM}$, と $\mathrm{K}^{+}$が細胞内液にほほ等しい高濃度であ る一方, $\mathrm{Na}^{+}$と $\mathrm{Ca}^{2+}$ は低く保たれている1)。また, 蝸牛の内リンパ腔には内リンパ直流電位（EP; endocochlear DC potential; 約 $90 \mathrm{mV}$ ) があり, 音 の機械的エネルギーを神経伝達のための電気信号 に変換するのに必要な駆動力として重要な役割を 担っている。

\section{内耳におけるイオンチャネルの役割}

これらの特異的な内リンパのイオン組成は, 内 リンパを取り囲む上皮細胞群に存在する様々なイ オンチャネル, ポンプ, トランスポーターによる 


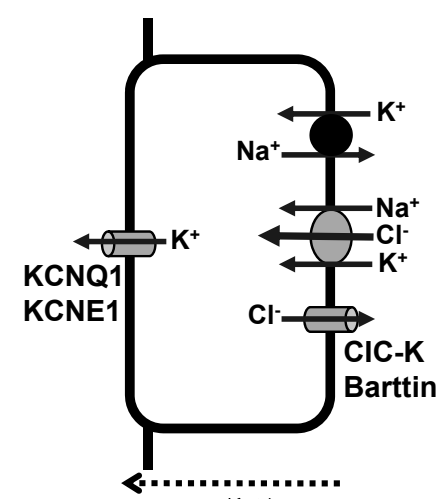

$\mathrm{K}^{+}$分泌

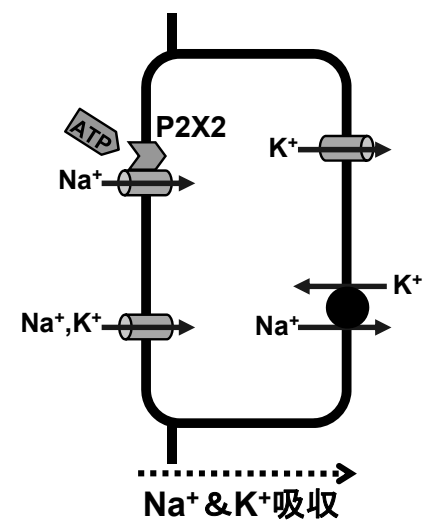

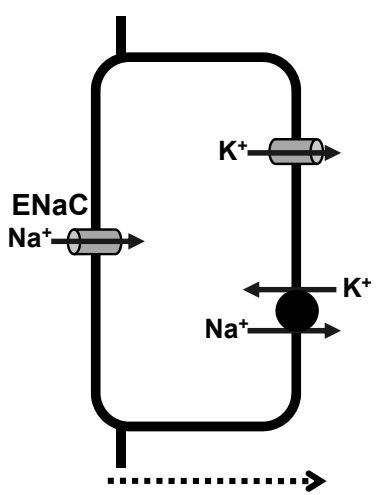

$\mathrm{Na}^{+}$吸収

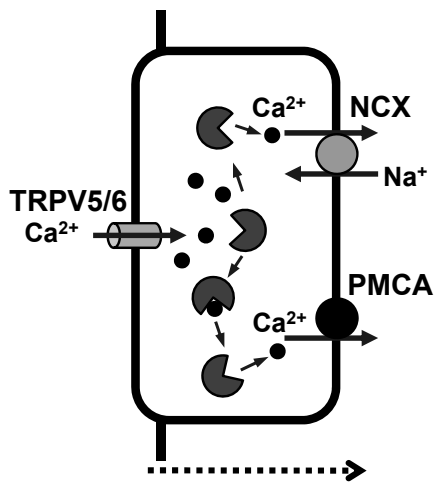

$\mathrm{Ca}^{2+}$ 吸収

図 1 内耳上皮組織におけるナトリウムイオン, カリウムイオン, カルシウムイオンのフロー。

イオンの能動的あるいは受動的輸送によって維持 されている $(\text { 図 } 1)^{2)}$ 。

\section{カリウムの流れ}

カリウムイオンは蝸牛血管条と前庭暗細胞より 内リンパヘ流出され高濃度を保っている。これら は, $\beta 2$ アドレナリン受容体, ムスカリン受容体, プリン受容体などの様々なシグナル伝達経路によ

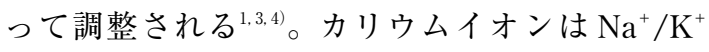
-ATPase と $\mathrm{Na}^{+} / \mathrm{K}^{+} / 2 \mathrm{Cl}^{-}$共輸送体によって外 リンパや血管条細胞外空間 intrastrial space から 汲み取られる。そして頂端側に存在するカリウム チャネル KCNQ 1/KCNE 1 を通して, 内リンパ へと分泌される。塩素イオンはクロライドチャネ ル CIC-K/Barttin を介して拡散する。内リンパの カリウムイオンは有毛細胞や外らせん溝細胞から 吸収される。

螖牛前庭階・鼓室階では電流が検出される
が5), これはカリウムイオンのコルチ器からの循 環, ライスネル膜からの漏洩もしくは輸送による ものと考えられている6。

\section{ナトリウムイオンの吸収}

内リンパ中のナトリウムイオン濃度は低く保た

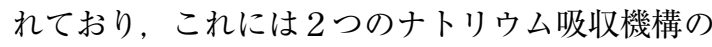
モデルが考えられている。一つは, 選択的ナトリ

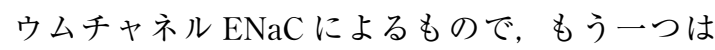
非選択的陽イオン吸収機構でカリウムイオンの吸 収にも与るものである。前者はライスネル膜と半

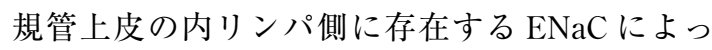
てナトリウムイオンが吸収される。また, $\mathrm{ENaC}$ の $\alpha$ サブユニットの発現は糖質コルチコイドによ って促進される。ナトリウムイオンは基底側の $\mathrm{Na}^{+} / \mathrm{K}^{+}$- ATPase によって外リンパへと汲み出 される ${ }^{7.8)}$ 。後者は蝸牛外らせん溝細胞と前庭移行 細胞の内リンパ側にある非選択的陽イオンチャネ 


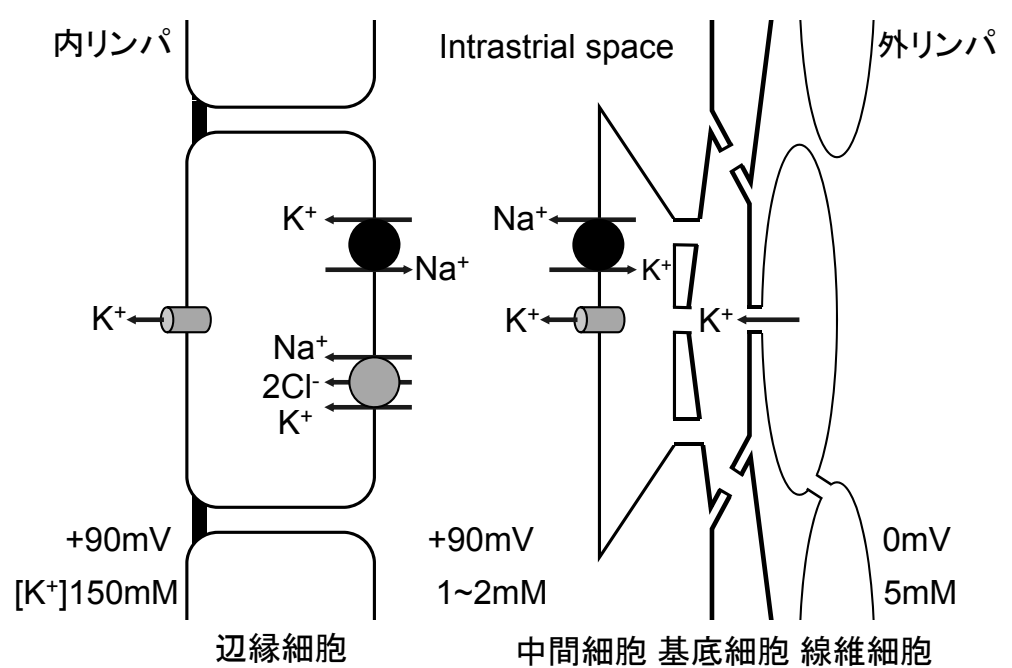

図２血管条におけるカリウムイオン輸送。

ルによる吸収機構で, カリウムイオンやカルシウ ムイオンの吸収も担っている。ここでもナトリウ ムイオンは基底側の $\mathrm{Na}^{+} / \mathrm{K}^{+}-$ATPase によって 外リンパヘと汲み出される ${ }^{9 \sim 11)}$ 。さらに螖牛外ら せん溝細胞ではプリンによって調節される非選択 的陽イオンチャネルによってもナトリウムイオン が吸収されている7゙。

\section{カルシウムイオンの吸収}

内リンパ中のカルシウムイオン濃度は低く保た れており，これには2つのカルシウム吸収機構の モデルが考えられている。一つは先に述べた蝸牛 外らせん溝細胞と前庭移行細胞にある非選択的陽 イオンチャネルによるカルシウムイオンの吸収で ある。もう一つはビタミン Dによって発現促進さ れる選択的カルシウムチャネル $\mathrm{ECaC}$ (TRPV5/ TRPV 6) によるカルシウム吸収機構である。 $\mathrm{ECaC}$ によって取り込まれたカルシウムイオンは細胞質 に存在するカルシウム結合蛋白であるカルビンデ イン $(\mathrm{D} 9 \mathrm{k} / \mathrm{D} 28 \mathrm{k})$ によって効率的に拡散され, 基底側の細胞膜カルシウム ATPase（PMCA 1) と $\mathrm{Na}^{+} / \mathrm{Ca}^{2+}$ exchanger (NCX 1) によって外リン パヘと分泌される ${ }^{12)}$ 。

\section{血管条におけるイオン機構}

蝸牛内リンパにおける高カリウム濃度と内リン パ電位は血管条で産生されている。その特異な構 造は, 図 2 に示すように, 辺縁細胞と, 中間細胞・ 基底細胞・線維細胞からなる機能的合胞体とで 2
重構造を形成し，その間隙が血管条細胞外空間 intrastrial spaceである。この血管条細胞外空間で は既に内リンパ電位と同等のプラスの電位が発生 しているのに対し， $\mathrm{K}^{+}$濃度は外リンパより更に 低くなり，辺縁細胞を隔てて内リンパで高濃度に 保たれている。この特異なイオン機構は電気生理 学的なイオン測定法であるイオン選択電極法 ion selective electrodes ${ }^{13)}$ や振動プローブ法 vibrating probe $^{7)}$ にて確かめられた。同様に前庭において も，暗細胞がカリウムイオンを内リンパヘ分泌し 高カリウム濃度を産生している事が確認され た ${ }^{14)}$ 。その後の様々な研究によって, 各種イオン チャネルやポンプ, トランスポーターなどが複雑 なイオン輸送を担い維持していることがわかって きた（図 1 )。

\section{内耳研究におけるイオン測定法}

内リンパにおけるカリウムイオンなどは電気生 理学的手法によって計測することができ，それに よって内耳の機能評価を可能にした。例えばイオ ン選択電極法による内リンパのイオン濃度, $\mathrm{pH}$ などの測定はin vivo では遺伝難聴モデル動物の 内耳機能の障害機序を推定するのに有用であ る ${ }^{15,16)}$ 。またin vitroでも卵形囊の 3 次元培養乇 デルが in vivo に近いカリウム濃度を維持してい たことが確かめられた ${ }^{17)}$ 。一方，振動プローブ法 によって新鮮な内耳上皮組織のイオン輸送を捉え ることができる714)。また，ウッシングチャンバ 


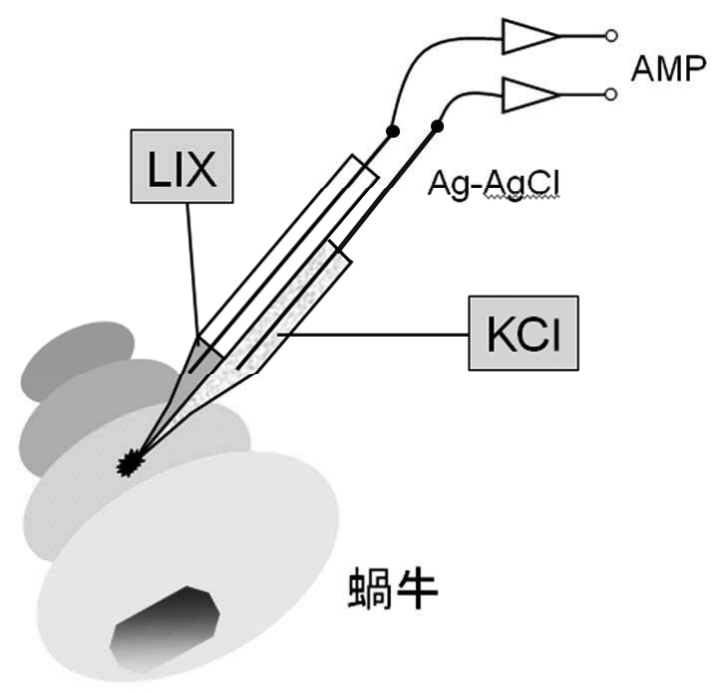

図3イオン選択電極法による内リンパ電位と イオン濃度測定。AMP 増幅器。

一法 Ussing chamberを用いると, 血管条辺縁細 胞や前庭暗細胞上皮などを用い in vitro でのイオ ン輸送を捉え, イオンチャネルの機能を調べるこ とも可能である ${ }^{18,19)}$ 。

イオンチャネルの局在やその機能を調べる電気 生理学的実験法としては, 単チャネルを測定でき るパッチクランプ patch clamp 法が優れた研究手 法として位置づけられている。この方法について は67-4 号掲載伊藤が詳しく解説しておられるの でご参照頂きたい。本項ではイオン選択電極法と 振動プローブ法などの電気生理学的手法を中心に して具体例などとともに解説する。

\section{イオン選択電極法}

液状イオン交換体 liquid ion exchanger を用い るとある特定のイオンを選択的に透過させる液状 の膜を形成できる。この性質を用いて，2本のガ ラス電極の一方に塩化ナトリウムや塩化カリウム 溶液を満たし, 他方に液状イオン交換体を満た し, 両方の電位の差を計測することで, Nernst の式 $\mathrm{E}=\mathrm{RT} / \mathrm{ZF} \ln \left([\mathrm{I}]_{\text {out }} /[\mathrm{I}]\right.$ in $)$ により計算し, イオン濃度を測定することができる。このときイ オン電荷によりイオン濃度の10倍変化に対する電 位差の増加が異なることに留意したい。すなわ ち, $37^{\circ} \mathrm{C}$ の条件下ではナトリウムイオンやカリウ ムイオンなどの 1 価イオンはおよそ $60 \mathrm{mV}$ ずつ
表1 哺乳類内耳の内外リンパに抢ける各イオンの 組成を示す。外リンパに比較して，内リンパ では主に $\mathrm{K}^{+}$濃度が著しく高く，逆に $\mathrm{Na}^{+}$が 低い。（2）ょり一部改変。

\begin{tabular}{|c|c|c|}
\hline & $\begin{array}{c}\text { 内リンパ } \\
\text { 蝸牛 } / \text { 前庭 }\end{array}$ & 外リンパ \\
\hline $\mathrm{K}^{+}$ & $157 / 149 \mathrm{mM}$ & $5 \mathrm{mM}$ \\
\hline $\mathrm{Na}^{+}$ & $1 / 9 \mathrm{mM}$ & $145 \mathrm{mM}$ \\
\hline $\mathrm{Ca}^{2+}$ & $20 / 200 \mu \mathrm{M}$ & $1 \mathrm{mM}$ \\
\hline $\mathrm{Cl}^{-}$ & $132 / 119 \mathrm{mM}$ & $120 \mathrm{mM}$ \\
\hline $\mathrm{HCO}_{3}^{-}$ & $31 / ? \mathrm{mM}$ & $20 \mathrm{mM}$ \\
\hline
\end{tabular}

変化するのに対し, カルシウムイオンなどの 2 価 イオンの場合には約 $30 \mathrm{mV}$ ずつ変化することに なる。また，異なる温度条件下でも測定值が変わ ってしまうことに注意しなければならないため, 実験動物を $37^{\circ} \mathrm{C}$ に維持するように温めるヒーター や，in vitro の実験では細胞の培養液などが一定 の温度を維持できるような装置が必須となる。各 種液状イオン交換体を表 2 に示す。水素イオンの 液状イオン交換体を用いれば， pH を測定できる ことになる。

特に内耳では内リンパの流出などでイオンのホ メオスターシスを損なうことがないように，でき るだけ小さい穿孔をあけて測定する。そのために は, 2 本の電極をひとまとめにした doublebarreled electrodes（図 3$)^{15)}$ を用いると良い。

Double-barreled electrodes は2本のフィラメ ント入りのガラス管（WPI 1 B 100 F-4）を用い, プーラー（PD-5ナリシゲ）にて熱しながら左右 に180度ずつ回してから引き伸ばし作成する。先 端の形状は測定目的のイオンによって調整が必要 なので, 加熱時間や牽引力を微妙に調整して行 う。液状イオン交換体を挿入するほうの後端を少 し長めに作成しておき， $200^{\circ} \mathrm{C}$ に熱したチャンバ 一に立て，この長いガラス管のみをシラン処理す る。（短いガラス管には小さく切ったパラフィル ムなどで栓をしておく。シランは猛毒なので必ず 換気フード内で行うこと。）短いガラス管に 150 $\mathrm{mM} \mathrm{KCl}\left(\mathrm{K}^{+}\right.$測定目的のときは $500 \mathrm{mM} \mathrm{NaCl}$ を 用いる。）を，長いガラス管に液状イオン交換体 を満たし銀一塩化銀電極を抻入する。このとき適 
表2 液状イオン交換体 Liquid Ion Exchanger。測定目的のイオンによって選択する。 $\mathrm{pH}$ 測定が目的の場合 $\mathrm{H}^{+}$を選択すればよい。(25) より改変。

\begin{tabular}{|c|c|c|}
\hline 測定イオン & 液状イオン交換体 & カタログ番号 \\
\hline $\mathrm{H}^{+}$ & 水素 イオノフォア $\mathrm{I}$-カクテル $\mathrm{A}, \mathrm{B}$ & Fluka 95291/95293 \\
\hline $\mathrm{H}^{+}$ & 水素 イオノフォア $\mathrm{II}-$ カクテル $\mathrm{A}$ & Fluka 95297 \\
\hline $\mathrm{K}^{+}$ & カリウム $\quad$ イオノフォア $\mathrm{I}$-カクテル $\mathrm{A}, \mathrm{B}$ & Fulka $60031 / 60398$ \\
\hline $\mathrm{Na}^{+}$ & ナトリウム イオノフォア $\mathrm{I}$-カクテル $\mathrm{A}$ & Fulka 71176 \\
\hline $\mathrm{Na}^{+}$ & ナトリウム $\quad$ イオノフォア $\quad$ II-カクテル $\mathrm{A}$ & Fulka 71178 \\
\hline $\mathrm{NH}_{4}^{+}$ & アンモニウム イオノフォア $\mathrm{I}$ アカクテル $\mathrm{A}, \mathrm{B}$ & Fulka 09879 \\
\hline $\mathrm{Ca}^{2+}$ & カルシウム イオノフォア $\mathrm{I}$-カクテル $\mathrm{A}$ & Fulka 21048 \\
\hline $\mathrm{Ca}^{2+}$ & カルシウム $\quad$ イオノフォア $\quad$ II-カクテル $\mathrm{A}$ & Fulka 21196 \\
\hline $\mathrm{Mg}^{2+}$ & マグネシウム イオノフォア $\quad$ II-カクテル $\mathrm{A}$ & Fulka 63085 \\
\hline $\mathrm{Cl}^{-}$ & 塩化物 イオノフォア $\mathrm{I}-$ カカクテ $\mathrm{A}$ & Fulka 24902 \\
\hline
\end{tabular}

当な溶液で後方を満たしてもよい。溶液が蒸発し ないように栓をしておく。

In vivo の測定時は体温 $\left(37^{\circ} \mathrm{C}\right)$ と同じ温度の calibration 用の溶液を準備しておく。例えば $\mathrm{K}^{+}$ の測定には $1,3 ， 10,30,100,150,300 \mathrm{mM}$ $\mathrm{K}^{+}$溶液を使用する。筆者らは動物を暖めるヒー ターが calibration 溶液用の試験管立てと一体にな った金属製のブロックを用いて, 動物と溶液の温 度を一定になるように工夫した。Calibration で得 られたグラフから，実際の測定值を計算しグラフ 化する。

\section{振動プローブ法}

振動プローブ法は1974年 Jaffe らによりはじめ て使用され，100-1000 Hzで振動する金属電極を 用い, 位相弁別検出器 (phase sensing detector; PSD）によって高感度に電位勾配を現象として計 測できる Self-referencing electrodesである ${ }^{13)}$ 。現 在は更に改良されたイオン選択電極で，特定のイ オンの流れを捉えることができる。すなわち振動 プローブ法によって, 上皮細胞からのイオンの流 出入を計測することができる。詳しい原理につい てはUniversity of Massachusetts Vibrating Probe Facility (http : // www. bio. umass. edu / biology / kunkel/nvp_umass.html) によくまとまっている ので興味のある方は是非参照いただきたい。

内耳における振動プローブ法による計測は特異 なイオン組成を持つ内リンパのイオンチャネルの 働きを直感的に捉える優れた手法である。Marcus
らは，カリウムイオンの排出と吸収が蝸牛と前庭 において類似した構造によって維持されているこ とを示した。すなわち, 蝸牛の血管条の辺縁細胞 と前庭の暗細胞 dark cell がカリウムイオンを分 泌しており, 蝸牛の外側溝細胞 (OSC) と前庭の 移行細胞（VTC）が吸収していることを示した。 また, OSC と VTCではナトリウムイオンも吸収 していることを証明し, non selective cation channelの存在を示唆した ${ }^{7.14)}$ 。

\section{ウッシングチャンバー法}

ウッシングチャンバー法は, 1950年に Ussing とZerahnによってカエルの表皮における $\mathrm{Na}$ 輸 送に応用された測定法である ${ }^{20)}$ 。溶液の水槽を 2 部屋に区切り，間に空を開けてそこに測定目的の 上皮膜を張り，両側に塩橋(生理的塩類溶液を $2-$ $3 \%$ 寒天で固めたもの) を介して電極を接続す る。電解質の流れ, 電気化学ポテンシャル, 透過 性といった膜輸送における電気化学的特性を, 電 流, 起電力, 電気抵抗といった電気回路の用語で 表現し, 膜輸送を電気的な等価回路として表す。 膜の電解質輸送を等価回路で表すと, 膜両側の溶 液で解離している電解質 $\mathrm{i}$ の能動輸送は, 抵抗 Ri と起電力 $\mathrm{Ei}$ を直列につないだ回路を流れる電流 Ii として表され, 抵抗 R $\Sigma$ は受動輸送における抵 抗の総和と考えることができる。ここで, 膜の両 側に存在する溶液の化学組成をまったく同じにし ておけば, 膜を介した電気化学ポテンシャル勾配 が無くなるので, 両溶液間の拡散電位は 0 になる 
はずである。したがって，もしもこのとき膜の両 側の溶液間で電位差が発生していれば，電解質が 何らかの能動的な駆動力によって輸送されている ことになる。これを起電性電解質輸送と呼び, ウ ッシングチャンバー法では短絡回路のスイッチが 開いていることから，このときの電位を開放回路 電位と呼ぶ。この開放回路電位が経上皮電位であ る。ここで, スイッチを閉じ, 外部の電池 Eext の電圧を調節して, 膜の両側溶液間の電位差が 0 になるように電圧固定したとすると, これは両溶 液間を短絡したことと同じこととなるので，この 状態を短絡回路状態と呼ぶ。このとき短絡回路を 流れる電流を短絡電流 short-circuit current (Isc) と呼び, これは, 膜を介した起電的電解質輸送に よる電解質の流れに相当した大きさの電流であ る。短絡電流法では, この短絡電流 Isc を測定す ることで, 上皮膜の起電的電解質輸送の指標とす る。Iscを記録しながら, 薬物を投与すれば, 薬 物投与による起電的電解質輸送の変化を Isc の変 化として連続的に記録することができる ${ }^{21)} 。$

内耳組織は微小であるため, マイクロウッシン グチャンバー法を用いた計測が成功している。須 納瀬らは, 血管条辺縁細胞や前庭暗細胞上皮など のカリウムイオンの頂端側への流出をマイクロウ ッシングチャンバー法によって Isc を測定するこ とでとらえることに成功している ${ }^{18,199}$ 。

\section{ラジオアイソトープ}

ラジオアイソトープを用いると, 比較的長い時 間の測定が可能なため, 緩やかなイオン輸送であ っても測定できる。上皮組織の頂端側と基底側で の放射性同位元素でラベルしたイオンの濃度変化 を捉える方法により, 上皮組織のイオンチャネル などがどれだけイオン輸送を行ったか計算する。 例としては, ラットの半規管上皮細胞を培養 し, ${ }^{45} \mathrm{Ca}^{2+}$ でラベルした培養液を頂端側と基底側 にそれぞれ浸し，ビタミンDやカルシウムチャネ ル阻害剤などによる変化を計測することで，半規 管膜の TRPV 5/TRPV 6 チャネルを中心としたカ ルシウム輸送機能が示された ${ }^{22)}$ 。

\section{その他の測定法について}

上述の電気生理学的手法の他にも Flu 2 による 細胞内カルシウムイオン測定法などがあるが, こ ちらは67- 2 号掲載原田の項をご参照いただきた い。最近では多焦点蛍光顕微鏡などの進歩によ
り，FM-143 などの蛍光色素を用いて有毛細胞の 機械受容チャネル mechanosensitive channel から の取り込みを機能的に解析する方法なども報告さ れている ${ }^{23)}$ 。

また, 電気生理学的手法に限らず, イオンチヤ ネルは蛋白質であるので, 免疫組織学的手法によ って，その局在を調べることができ， ウェスタン ブロッド法や RT-PCR によって蛋白質や RNAの 発現を証明する方法も一般的である。近年では分 子生物学, 分子遺伝学の進歩により, 機能評価と しての電気生理学的手法と組み合わせて総合的に イオンチャネルの研究が行われている。ある細胞 株にイオンチャネルの遺伝子を導入することで,

人工的な環境を作り出し, 分子生物学的手法や電 気生理学的手法を用いて, そのイオンチャネルの 構造や機能を詳しく解析することもできる。Peng らはアフリカツメガエル卵母細胞に先に述べた TRPV 5/TRPV 6 チャネルをクローニングし, 電 気生理学的手法にてチャネルの特性を調べてい $ろ^{24)}$ 。

\section{まとめ}

イオンチャネルの研究が始まってから約半世紀 が過ぎたが，様々に工夫された電気生理学的実験 法によって, 生体にとってそれが重要な役割を果 たしていることが明らかになっていった。1980年 代以降は分子生物学の目覚ましい進歩により, 構 造解析が進みその機能が明らかとなっていった。 そして今日では分子遺伝学の発展によって, さら に多様で複雑な実験が可能となり, 今後はナノテ クノロジーの進歩などによって更なる発見や応用 が期待されている。内耳研究においてもこれらの 実験方法をうまく組み合わせて, 病態解明や治療 の開発へと発展し, 患者への福音となることを願 う。

\section{文献}

1) Wangemann P, Schacht J: Homeostatic mechanisms in the cochlea. In ed Dallos P, Popper AN, Fay RR. The Cochlea. pp 130185, Springer-Verlag, New York, 1996

2 ) Marcus D, Pondugula S, Lee J, et al: Iontransport pathways in the cochlea and vestibular labyrinth. 5 th International Symposium Meniere's Disease \& Inner Ear Homeostasis Disorders, pp 40, 2005 
3) Wangemann P, Shen Z, Liu J: K(+)-induced stimulation of $\mathrm{K}+$ secretion involves activation of the IsK channel in vestibular dark cells. Hear Res 100: 201-210, 1996

4 ) Wangemann P, Liu J, Shimozono M, et al: Beta 1-adrenergic receptors but not beta 2adrenergic or vasopressin receptors regulate $\mathrm{K}+$ secretion in vestibular dark cells of the inner ear. J Membr Biol 170: 67-77, 1999

5 ) Zidanic M, Brownell WE: Fine structure of the intracochlear potential field. I. The silent current. Biophys J 57: 1253-1268, 1990

6 ) Wangemann P: K+ cycling and the endocochlear potential. Hear Res 165: 1-9, 2002

7 ) Lee JH, Marcus DC: Endolymphatic sodium homeostasis by Reissner's membrane. Neuroscience 119: 3-8, 2003

8 ) Pondugula SR, Sanneman JD, Wangemann P, et al: Glucocorticoids stimulate cation absorption by semicircular canal duct epithelium via epithelial sodium channel. Am J Physiol Renal Physiol 286: 1127-1135, 2004

9 ) Chiba T, Marcus DC: Nonselective cation and BK channels in apical membrane of outer sulcus epithelial cells. J Membr Biol 174: 167-179, 2000

10) Marcus DC, Chiba $\mathrm{T}: \mathrm{K}+$ and $\mathrm{Na}+$ absorption by outer sulcus epithelial cells. Hear Res 134: 48-56, 1999

11) Thorne PR, Munoz DJ, Housley GD: Purinergic modulation of cochlear partition resistance and its effect on the endocochlear potential in the guinea pig. J Assoc Res Otolaryngol 5: 58-65, 2004

12) Yamauchi D, Raveendran NN, Pondugula SR, et al: Vitamin D upregulates expression of ECaC 1 mRNA in semicircular canal. Biochem Biophys Res Commun 331: 1353-1357, 2005

13) Marcus DC: Acoustic transduction. In ed Sperelakis N. Cell Physiology sourcebook. 3 ed. pp 775-794, Academinc press, 2008

14) Lee JH, Chiba T, Marcus DC: P $2 X 2$ receptor mediates stimulation of parasensory cat- ion absorption by cochlear outer sulcus cells and vestibular transitional cells. J Neurosci 21: 9168-9174, 2001

15) Gow A, Davies C, Southwood CM, et al: Deafness in Claudin 11-null mice reveals the critical contribution of basal cell tight junctions to stria vascularis function. J Neurosci 24: 7051-7062, 2004

16) Wangemann $\mathrm{P}$, Nakaya $\mathrm{K}, \mathrm{Wu} \mathrm{T}$, et al: Loss of cochlear HCO 3- secretion causes deafness via endolymphatic acidification and inhibition of $\mathrm{Ca} 2+$ reabsorption in a Pendred syndrome mouse model. Am J Physiol Renal Physiol 292: 1345-1353, 2007

17) Gaboyard S, Chabbert C, Travo C, et al: Three-dimensional culture of newborn rat utricle using an extracellular matrix promotes formation of a cyst. Neuroscience 133: 253265, 2005

18) Sunose H, Liu J, Marcus DC: cAMP increases $\mathrm{K}+$ secretion via activation of apical IsK/KvLQT 1 channels in strial marginal cells. Hear Res 114: 107-116, 1997

19) Sunose H, Liu J, Shen $Z$, et al: cAMP increases apical IsK channel current and $\mathrm{K}+\mathrm{se}-$ cretion in vestibular dark cells. J Membr Biol 156: 25-35, 1997

20) Ussing HH, Zerahn K: Active transport of sodium as the source of electric current in the short-circuited isolated frog skin. Acta Physiol Scand 23: 110-127, 1951

21）唐木晋一郎, 桑原厚和：上皮膜における電解 質輸送の電気生理学的測定法 : 短絡電流法. 日薬理誌 $123: 211-218,2004$

22) Nakaya K, Harbidge DG, Wangemann P, et al: Lack of pendrin HCO 3- transport elevates vestibular endolymphatic [Ca $2+]$ by inhibition of acid-sensitive TRPV 5 and TRPV 6 channels. Am J Physiol Renal Physiol 292: 1314-1321, 2007

23) Meyers JR, MacDonald RB, Duggan A, et al: Lighting up the senses: FM 1-43 loading of sensory cells through nonselective ion channels. J Neurosci 23: 4054-4065, 2003 
24) Peng JB, Brown EM, Hediger MA: Epithelial Ca $2+$ entry channels: transcellular $\mathrm{Ca} 2+$ transport and beyond. J Physiol 551: 729-740, 2003

25) Voipio J, Pasternack M, Macleod K: Ion- sensitive microelectrodes. In ed Ogden DC. Microelectrode techniques, The Plymouth workshop handbook. $2^{\text {nd }}$. pp 275-316, Company of Biologists, Cambridge, 1994 